\title{
Analysis of Technical Efficiency of Poultry Farmers in Cross River State, Nigeria
}

\author{
Ewung Bethel ${ }^{1}$, Djomo Raoul Fani ${ }^{1}$, Egbeadumah Maryanne Odufa ${ }^{2}$ \\ Department of Agricultural Economics, University of Agriculture, Makurdi. Benue-State, Nigeria \\ Department of Agricultural Economics and Extension, Federal University Wukari, PMB 1020 \\ Wukari. Taraba State, Nigeria \\ raoulfani@gmail.com
}

\begin{abstract}
It has been reported that one of the major challenge faced by Nigerian today is lack of adequate protein intake both in quality to feed the nations ever-growing population. Therefore, this study was carried out to analyze technical efficiency of poultry farmers in Cross River State, Nigeria. A purposive and random sampling technique was used to select 295 poultry farmers. Data were collected using structured questionnaires and interview schedule, administered on the respondents were analyzed using descriptive statistics and stochastic frontier production functions. The estimated production function of day-old chicks was significant at $1 \%$ level implying that percentage increase of chicks will increase output by 0.401 percent. The coefficients of extension visit, membership of association and credit were found negative implying that the variables increase technical efficiency of poultry farmers. Also, the mean technical efficiency for poultry farmers is 58 percent implying that technical efficiency could be increased by 42 percent given the current level of technology if the available resources are efficiently utilized. It is therefore recommended that: access and use of credit should be encouraged because it can significantly improve productivity and welfare. Government should also encourage extension visit as well as membership of association to poultry farmers in order to increase their efficiency the Study Area.
\end{abstract}

Keywords: Technical, Efficiency, Poultry, Farmers

\section{INTRODUCTION}

Agriculture continues to be a strategic sector in the development of most low-income nations. It employs about $40 \%$ of the active labor force globally. In sub-Saharan Africa, Asia and the Pacific, the agriculture-dependent population is over 60\%, while in Latin America and high income economies the proportions are estimated at $18 \%$ and $4 \%$, respectively (World Bank,

2006). Increased incomes, urbanization and population growth is expected to lead in increasing demand of animal products in the developing world, which can in turn improve incomes of poor farmers and food processors. It is expected, that the demand for animal products will increase by about 50 percent from 19993 to 2020 and mostly attributed to developing countries (Delgado et al. 1999). In sub-Saharan Africa (SSA) total consumption of meat and milk is expected to double between 1997 and 2020 to reach 11.3 and 35.4 million tonnes (Simon $\boldsymbol{e t}$ al. 2002). This expected increase in demand for animal products has profound implications for food security and poverty alleviation among rural people in SSA. In particular, the expected demand for livestock products presents expanding market opportunities for poor smallholder livestock producers (Sirak and Siegfried, 2007). One of the greatest problems confronting millions of Nigerian today is lack of adequate protein intake both in quality to feed the nations ever-growing population. This inadequacy results in problem of malnutrition. The resultant effect of serious deficiency in the amount of protein intake is that people's health is adversely affected; particularly the mental capability, working productivity and eventually, the overall national economic growth (Okoruwa and Olakanmi, 1999, Kareem et al. 2008). It has also been observed that one of the most serious constraints of agricultural growth in Nigeria is the inefficient use of productive resources and that considerable growth can be achieved by simply improving the level of efficiency in resource use (Fabiyi and Adegboye, 1978; Ogunfowora, 1975, Kareem et al. 2008). Technical efficiency is the ability to produce a given level of output with a minimum quantity of inputs under a given technology. Efficiency is also an important 
factor in productivity growth. In an economy where resources are scarce and opportunities for new technologies are lacking, inefficiency studies will be able to show that it is possible to raise productivity by improving efficiency without increasing the resource base or developing new technology. Estimates of the extent of inefficiency also help in deciding whether to improve efficiency or to develop new technologies to raise agricultural productivity (Tijani, 2006). Numerous studies (e.g. Obwona, 2000; Son et al, 1993) have attempted to determine technical efficiencies of farmers in developing countries because determining the efficiency status of farmers is important for policy purposes (Tijani, 2006). Therefore, this study analyzed technical efficiency of poultry farmers in Cross River State, Nigeria.

\section{THEORETICAL FRAMEWORK}

\section{Cobb-Douglas Production Function}

The theoretical basis of this study focused on Cobb-Douglas (CD) production function which shows a functional relationship between inputs and output. The Cobb-Douglas (CD) function further assumes constant returns to scale and unitary elasticity of substitution.

For two variable inputs, the function can be expressed as $\mathrm{Y}=A L^{b 1} \mathrm{~K}^{\mathrm{b} 2} \mathrm{e}$

Where $\mathrm{Y}=$ level of output, $\mathrm{L}$ and $\mathrm{K}=$ variable inputs, $\mathrm{A}=$ multiplicative constant, $\mathrm{b}^{1}$ and $\mathrm{b}^{2}$ are the coefficient of $\mathrm{L}$ and $\mathrm{K}$ and they represent the direct measure of elasticity of the respective factors of production, and $\mathrm{e}=$ error term. The sum of $\mathrm{b}^{1}$ and $\mathrm{b}^{2}$ indicates the nature of returns to scale. Upton (1979); Terfa and Terwase (2011) observed that, the Cobb-Douglas production function cannot show both increasing and diminishing marginal productivity in a single response curve and as a result it does not give a technical optimum and may lead to the over estimation of the economic optimum. Despite these disadvantages researchers still find the Cobb-Douglas production function useful in analysis of survey where many variable inputs are involved and it is necessary to measure returns to scale, intensity of factors of production and overall efficiency of production. It can also provide a means of obtaining coefficients for testing hypotheses (Cobb and Douglas 1928; Erhabor, 1982; Terfa and Terwase, 2011). While commenting on the superiority of Cobb-Douglas production function over other forms of production functions, Terfa and Terwase (2011) stated that, Cobb-Douglas production function is used more than the other two because it satisfies the economic, statistical and econometric criteria of many studies than others.

\section{EMPERICAL REVIEW}

Obwona, (2006) identified education, credit accessibility and extension services as variables that contribute positively towards the improvement of efficiency and of course productivity of 65 sampled small and medium-scale tobacco farmers in Uganda. Ajibefun and Daramola (2003) highlighted education and age among other determinants of the level of efficiency of micro enterprise in Nigeria. According to Rhaji (2005), credit access for adopters and non-adopters of improved management practices were found to be significant as determinants to the production efficiency of rice in Niger state, north central Nigeria. Bhasin and Akpalu (2001), also noted from the result of their work that business experience, training programme and credit among other variables were found to be statistically significant to the efficiency of micro-enterprises (hair dressers, dressmakers, and wood processor) in Cape Coast. Amaza and Maurice (2005) carried out a study which had as objective the identification of factors that influence technical efficiency in rice-based production systems in Nigeria. They found that there were wide efficiency differentials among farmers in the study area and that rice-based crop production could be increased by $20 \%$ through better use of resources. Farmerspecific factors such as education and farming experience were found to contribute positively and significantly to farmers' efficiency levels in the rice-based production. Onyenweaku and Ohajianya (2005) found a positive relationship between education and technical efficiency in rice production in their study of swamp and upland rice farms in south-eastern Nigeria. Aye and Mungatana (2012) reported that improved maize seed, inorganic fertilizers, conservation practices, size of farm holdings, education, and access to extension services, credit and market were found to have significant impact on efficiency of maize farmers in Nigeria.

\section{MeThODOLOGY}

The Study Area: The study was carried out in Cross River state, south -south Nigeria. The state was created in 1967 from part of the former Eastern region, and was known as the south eastern state until 
1976 when it adopted its present name. The state originally included what is now called Akwa Ibom state. Cross River State is a coastal state with an estimated population of 3,104,446 million (census, 2006). It has a land mass area of $20,156 \mathrm{~km}^{2}$ bordering Cameroon to the east. It is named for the cross river which passes through the state. Its capital is Calabar, and consists of 18 local government areas with three major languages of Efik, Ejagham and Bekwara cutting across the three senatorial district of south, central and north respectively.

Population, Sampling Procedure and Data Collection: A two-stage sampling technique was adopted. The first stage was purposive sampling of six local government areas. This was done in due regards to the relative concentration of farms in these areas, viz; Calabar (193), Akamkpa (26), Ikom (32), Obubra (25), Ogoja (15) and Yala (4) local government areas. Data for the number of farms enclosed in brackets were gotten from the Cross River State Ministry of Agriculture, department of livestock development and services 2007. Registered farm had a minimum of two hundred (200) birds in farm. The second stage follows a random sampling process of three local government areas which are Calabar, Ikom and Ogoja. Data were collected from poultry farmers of the sampled area through a well structured questionnaire. Particularly, data was collected from respondent in three local government areas including Ogoja, Ikom, and Calabar through a random sampling process.

Variable Specification/Model Specification: The Cobb- Douglas frontier production function. The model is represented as:

$\operatorname{In} Y_{i}=a_{o}+a_{i} \operatorname{In} X_{i j}+V_{i}-U_{i}$

The inefficiency of production was modelled in terms of the factors that are assumed to affect the efficiency of production of the farmers. Such factors are assumed to be independently distributed such that $\mathrm{U}_{\mathrm{i}}$ is obtained by truncation (at zero) of the normal distribution with variance $\delta^{2}$ and mean $\mathrm{u}$ where the mean is defined by

$\mathrm{U}_{\mathrm{i}}=\sigma_{0}+\sigma_{1} \mathrm{Z}_{1}+\sigma_{2} \mathrm{Z}_{2}+\sigma_{3} \mathrm{Z}_{3}+\sigma_{4} \mathrm{Z}_{4}+\sigma_{5} \mathrm{Z}_{5}+\sigma_{6} \mathrm{Z}_{6}+\sigma_{7} \mathrm{Z}_{7}+\sigma_{8} \mathrm{Z}_{8}+\sigma_{9} \mathrm{Z}_{9}+\sigma_{10} \mathrm{Z}_{10}$

Where;

$Y_{i}=$ output (value in naira of eggs, spent layers and market weight broilers and cockerels sold) as dependent variable

$\mathrm{a}_{\mathrm{i}}=$ parameter

$\mathrm{X}_{\mathrm{ij}}=$ independent variables including:

$\sigma=$ a vector of unknown parameters to be estimated

\section{Production Efficiency Variables}

$\mathrm{X}_{1}=$ cost of labour in naira

$\mathrm{X}_{2}=$ number of day-old chicks

$\mathrm{X}_{3}=$ quantity of water in litres

$\mathrm{X}_{4}=$ cost of veterinary services, in naira

$\mathrm{X}_{5}=$ feed in number of bags ( $25 \mathrm{~kg}$ bags)

\section{Technical Efficiency Variables}

$\mathrm{Z}_{1}=$ gender, ( 1 for male, 0 otherwise)

$\mathrm{Z}_{2}=$ Age of household head (in years)

$\mathrm{Z}_{3}=$ Educational level, (1 for above primary, 0 otherwise)

$\mathrm{Z}_{4}=$ household size (number of person living in each household)

$Z_{5}=$ years of experience in poultry farming

$\mathrm{Z}_{6}=$ Distance from enterprise to lending institution

$\mathrm{Z}_{7}=$ training, attended training 1,0 otherwise

$\mathrm{Z}_{8}=$ extension visit in number of times visited 
$\mathrm{Z}_{9}=$ membership of association (1, if yes and 0 otherwise)

$\mathrm{Z}_{10}=$ credit (1 if received, 0 otherwise)

\section{RESULTS AND DISCUSSION}

Table1: Maximum Likelihood Estimates of parameter of Cobb-Douglass Stochastic frontier Production function

\begin{tabular}{|c|c|c|c|}
\hline Variables & Coefficient & Std-Error & T ratio \\
\hline $\begin{array}{c}\text { Stochastic frontier } \\
\text { Constant } \\
\text { X1 (Labour) } \\
\text { X2 (Chicks) } \\
\text { X3 (water) } \\
\text { X4 (Vet services) } \\
\text { X5 (feed) }\end{array}$ & $\begin{array}{c}10.224 * * * \\
0.094 \\
0.401 * * * \\
0.058 \\
0.055 \\
0.074\end{array}$ & $\begin{array}{c}0.654 \\
0.74 \\
0.071 \\
0.058 \\
0.053 \\
0.046\end{array}$ & $\begin{array}{l}15.634 \\
1.275 \\
5.695 \\
0.959 \\
1.027 \\
1.599\end{array}$ \\
\hline $\begin{array}{c}\text { Inefficiency Model } \\
\text { Constant } \\
\mathrm{Z}_{1} \text { (Gender) } \\
\mathrm{Z}_{2} \text { (Age of farmers) } \\
\mathrm{Z}_{3} \text { (Educational level) } \\
\mathrm{Z}_{4} \text { (Household size) } \\
\mathrm{Z}_{5} \text { (Years of experience } \\
\mathrm{Z}_{6} \text { ( Distance) } \\
\mathrm{Z}_{7} \text { (Training) } \\
\mathrm{Z}_{8} \text { (Extension visit) } \\
\mathrm{Z}_{9} \text { (membership of association) } \\
\mathrm{Z}_{10} \text { (credit) }\end{array}$ & $\begin{array}{c}4.117 \\
-0.1682 \\
-0.7932 \\
0.1734 \\
-0.4163 \\
0.1734 \\
-0.6387 \\
0.3085 \\
-0.999 * * * \\
-0.987 * \\
-0.5755^{*} *\end{array}$ & $\begin{array}{l}2.359 \\
0.783 \\
0.656 \\
0.783 \\
0.280 \\
0.783 \\
0.242 \\
0.717 \\
0.151 \\
0.512 \\
0.353\end{array}$ & $\begin{array}{c}0.175 \\
-0.215 \\
-0.121 \\
0.223 \\
-1.485 \\
10.223 \\
-0.147 \\
0.429 \\
6.626 \\
-1.923 \\
2.378\end{array}$ \\
\hline $\begin{array}{c}\text { Variance Parameters } \\
\text { Sigma squared } \sigma^{2} \\
\text { Gamma } \gamma\end{array}$ & $\begin{array}{l}1.219 * * * \\
0.949 * * *\end{array}$ & $\begin{array}{l}0.355 \\
0.024\end{array}$ & $\begin{array}{c}3.456 \\
39.317\end{array}$ \\
\hline
\end{tabular}

$*, * *, * * *$ significant at $10 \%, 5 \%$ and $1 \%$ levels respectively

The variance parameters for $\sigma^{2}$ and $\gamma$ are 1.219 and 0.949 . They are statistically significant at the $1 \%$ level. The gamma indicates that systematic influences that are unexplained by the production function are the dominant sources of random errors. While the sigma squared indicates the goodness of fit and correctness of the distributional form around for the composite error term. This indicates that the inefficiency effects make significant contribution to the economic efficiencies of farmers.

The estimated coefficient for the all independent variables, (i.e. chicks, feeds, water, labour, and veterinary services) had positive signs. However, only the variable of number of day -old chicks was significant at $1 \%$ level. This implies that a one percent increase the level of chicks will increase output by 0.401 percent.

The result of the inefficiency model shows that the coefficients of extension visit, membership of association and credit are significant variable that affect farmer's efficiency. The signs on the coefficients in the inefficiency model are interpreted in the opposite way, such that a negative sign means that the variable increases efficiency and a positive sign means that it decreases technical efficiency.

The result shows that an increased in the number of extension contact by farmers will increase technical efficiency. Extension contact improves farmer awareness of new innovation and methods that can improve efficiency. Extension visit was found to be statistically significant at $1 \%$ level. Again membership of the farmers in poultry association was found to be statistically significant at $10 \%$ level. It had a negative relationship with technical inefficiency. Members tend to share business experience and ideas at association level which can improve efficiency of farmers.

Credit was found to be statistically significant at 5\% level. This implies that credit access was a determining factor of the efficiency of the farmers in the study area. The negative sign of the coefficient reveals that inefficiency reduces with the use of credit. Also, an increase in the amount of credit accessed and efficiently utilized by farmers can significantly increase productivity. 
Table2. Efficiency Estimates: The computed technical efficiency varies between 0.24 and 0.98 with a mean value of 0.58 . This result implies that technical efficiency of poultry farmers could be increased by $42 \%$ given the current level of technology if the available resources are efficiently utilized.

\section{Description of Efficiency estimate}

\begin{tabular}{|c|c|}
\hline Efficiency estimate & Frequency \\
\hline $0-0.1$ & 4 \\
\hline $0.11-0.20$ & 13 \\
\hline $0.21-0.30$ & 10 \\
\hline $0.31-0.40$ & 13 \\
\hline $0.41-0.50$ & 18 \\
\hline $0.51-0.60$ & 20 \\
\hline $0.61-0.70$ & 22 \\
\hline $0.71-0.80$ & 19 \\
\hline $0.81-0.90$ & 24 \\
\hline$>0.90$ & 4 \\
\hline
\end{tabular}

Figure1. Graphical repre sentation of efficiency estimate of the farmers

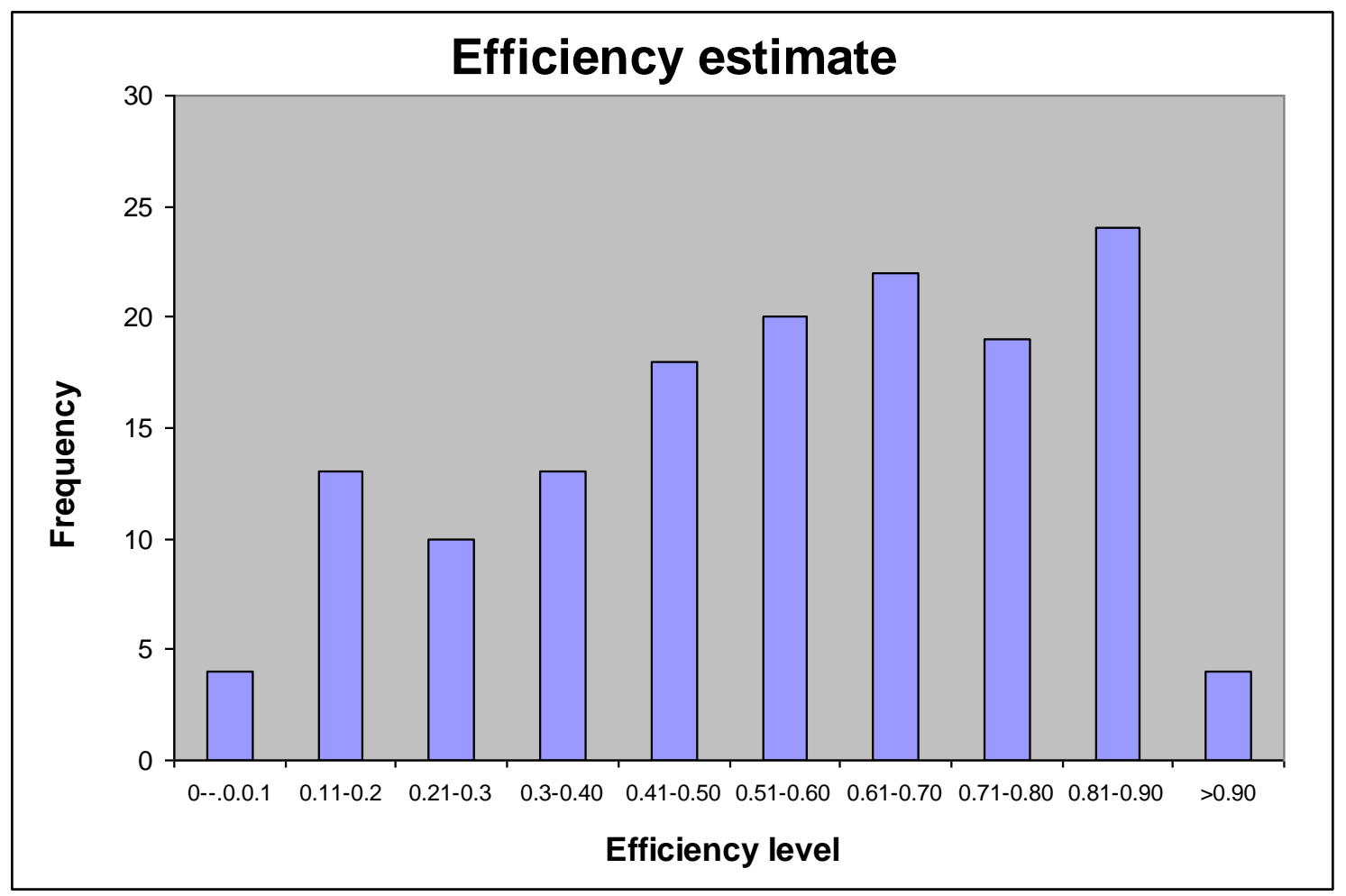

\section{CONCLUSION AND RECOMMENDATIONS}

This Study was carried out to analyze technical efficiency of poultry farmers in Cross River State, Nigeria. The results revealed that the estimated coefficient for the all independent variables, (i.e. chicks, feeds, water, labour, and veterinary services) had positive signs. However, only the variable of number of day -old chicks was significant at $1 \%$ level implying that percentage increase of chicks will increase output by 0.401 percent. The coefficients of extension visit, membership of association and credit were found negative implying that the variables increase technical efficiency of poultry farmers. Also, the mean technical efficiency for poultry farmers is 58 percent. This suggests that technical efficiency could be increased by 42 percent given the current level of technology if the available resources are efficiently utilized. It is therefore recommended that:

i) Access and use of credit should be encouraged because it can significantly improve productivity and welfare.

ii) Government should encourage extension visit as well as membership of association to poultry farmers in order to increase their productivity the study area.

iii) Since poultry farmers are relatively technically efficient experience farmers should be encouraged to remain into the business 


\section{REFERENCES}

Ajibefun, I.A.and G.Daramola, (2003). "Efficiency of Micro Enterprise in Nigerian Economy." AERC Research paper 134. African Economic Research Consortium Nairobi.

Amaza, P.S. and Maurice, D.C. (2005). Identification of Factors That Influence Technical Efficiency in Rice-Based Production systems in Nigeria, International Institute of Tropical Agriculture: Paper Presented at a Workshop on Policies and Strategies for Promoting Rice Production and Food Security in Sub-Saharan Africa. 7-9 November. P.20.

Aye, C.G and Mungatana. E.D. (2012). Evaluating the Performance of Maize Farmers in Nigeria using Stochastic Distance and Stochastic Production Frontiers. Journal of Human Ecology, 40(2): 177-188.

Bhasin, V. K. and W. Akpalu, (2001). “ impact of microfinance enterprises on the efficiency of micro enterprises in cape coast". International labour organization.

Cobb, C.W. and Douglas, P.H. (1928) "A Theory of production" American economic review supplement 18: $139-165$.

Delgado, C., Mark, R., Henning, S., Simeon, E., and Claude, C (1999). Livestock to 2020: The Next Food Revolution. Food, Agriculture, and the Environment Discussion Paper 28. Washington, D. C.: International Food Policy Research Institute (IFPRI).

Erhobor, P.O. (1982) "Efficiency of Resources use under small Scale Irrigation Technology in Nigeria" Purdue University; Water Resources Research Center West Lafayettse, Indiana, USA.Technical Report No 148 pp 1-114.

Fabiyi YL, Adegboye RO (1978). Land Tenure Reform in Nigeria; Implication of the Land Use Decree for Agricultural Development. Ife Journal of Agriculture., OAU, Ile-Ife. 1(2): 1-5.

Kareem, R. O, Dipeolu, A. O, Aromolaran, A. B and Akegbejo-Samson. (2008). Analysis of technical, allocative and economic efficiency of different pond systems in Ogun state, Nigeria. African Journal of Agricultural Research Vol. 3 (4): 246-254.

Obwona, M. (2000). Determinants of technical efficiency differentials amongst small and medium scale farmers in Uganda: A case of tobacco growers. A final report presented at AERC bi-annual workshop at Grand Requency Hotel, Nairobi, Kenya.

Ogunfowora (1975). Resources Productivity in Traditional Agricultural Division of Kwara State of Nigeria. Journal of Rural Economy and Development 9 (2):119-131.

Okoruwa, V.O., Olakanmi, A.O. (1999). Consumption pattern of Sheep and Goat Meat in Ibadan Metropolis: Implication for Food and Nutrition Policies. Trop. J. of Anim. Sci. 2 (1): 175-184.

Onyenweaku, C.E. and Ohajianya, D.O. (2005). Technical Efficiency of Swamp and Upland Rice Farms in South Eastern Nigeria. Journal of sustainable tropical agriculture Resources.Vol(14): 64-70.

Rahji M.A.Y. (2005). “ Determinants of Efficiency Differentials in lowland Rice Production Systems in Niger state Nigeria." Ibadan Journal of Agricultural research. Vol. I No.1: 1-17.

Simeon, E., Samuel, B., Timothy, W. and SIET, M. (2002). Food Security in Sub-Saharan Africa to 2020. Socioeconomics and Policy Research Working Paper 49. Nairobi, Kenya: International Livestock Research Institute (ILRI).

Sirak.T. B. and Siegfried, B. (2007). Analysis of The Determinants of Market Participation Within The South African Small-Scale Livestock Sector. Tropentag Paper. October 9-11. Pp.1-8.

Son, T.V.H., Coelli, T and Fleming, E. (1993). Analysis of the technical efficiency of state rubber farm in Vietnam. Journal of Agricultural Economics 9:183-201.

Terfa, D.A. and Terwase, S. (2011). Efficiency of Resource Use in Rice Farming Enterprise in Kwande Local Government Area of Benue State, Nigeria. International Journal of Humanities and Social Science Vol. 1 No. 3; March 201.pp. 4-6.

Tijani, A.A. (2006). Analysis of the technical efficiency of rice farms in Ijesha Land of Osun State, Nigeria. Agrekon, Vol 45(2):126-135

Upton, M. (1979). Farm Management in Africa: The Principles of Production and Planning. Oxford University, Oxford 260pp.

World Bank (2006). Where is the wealth of nations? Measuring capital for the 21 st century.World Bank, Washington, DC. 